\title{
Late Palaeocene- Early Eocene Morozovella from Pondicherry Area, Cauvery Basin, Southern India
}

\section{Bhargava Sharma C S, Chethan Kumar S and N Malarkodi* \\ Department of Geology, Bangalore University, India}

*Corresponding author: Nallamuthu Malarkodi, Department of Geology, Bangalore

Review Article
Volume 2 Issue 1
Received Date: December 12, 2018
Published Date: January 25, 2019

Published Date: January 25, 2019

University, Bangalore - 560 056, India, Tel: +91-9632584468; Email: nallamuthumalarkodi@gmail.com

\section{Abstract}

This paper records the occurrence of fourteen species of well-preserved planktonic foraminiferal genus Morozovella viz., Morozovella aequa, M. angulata, M. subbotinae, M. gracilis, M. velascoensis, M. formosa, M. apanthesma, M. acutispira, M. praeangulata, M. occlusa, M. acuta, M. conicotruncata,, M. lensiformis, and M. crater from several outcrops sections in the Pondicherry area, southern India. The recorded planktonic foraminiferal genus is useful for biostratigraphic purpose and indicates late Palaeocene-early Eocene (P3-E4 Zone) for the study area. These species are distinctive of tropical and subtropical environments of late Palaeocene and early Eocene

Keywords: Morozovella Foraminifera; Pondicherry; Palaeocene; Eocene; Cauvery Basin; Southern India

\section{Introduction}

The Pondicherry area includes the northernmost of the three outcrops of marine sediments and occupy an area of nearly 30 sq. miles NW of Pondicherry. The study area is situated to the NE of the city of Pondicherry where Palaeocene to early Eocene rocks are well exposed. The present field investigation led to the recognition of a welldefined stratigraphic section in the village of Saidarpet (N $\left.11^{\circ} 59^{\prime} 36.7^{\prime \prime}: \mathrm{E}^{\circ} 9^{\circ} 45^{\prime} 0.5^{\prime \prime}\right)$; calcareous marlstone and claystone were collected from the $\mathrm{NE}$ of the village Tiruchitrabalam - Saidarpet (N $12^{\circ} 00^{\prime} 5.3^{\prime \prime}:$ E79 $\left.{ }^{\circ} 46^{\prime} 33.6^{\prime \prime}\right)$ and calcareous fined grained sandstone, behind the temple of the village Papanchavadi $\left(\mathrm{N} 12^{\circ} 00^{\prime} 49.0^{\prime \prime}: \mathrm{E}^{\circ} 9^{\circ} 46^{\prime} 08.7^{\prime \prime}\right)$ and in the pond section of the village Ravathamkuppam $\left(\mathrm{N} 12^{\mathrm{O}} 00^{\prime} 55.7^{\prime \prime}: \mathrm{E}^{\circ} 9^{\mathrm{O}} 46^{\prime} 33.6^{\prime \prime}\right)$ in the Pondicherry area (Figure 1).

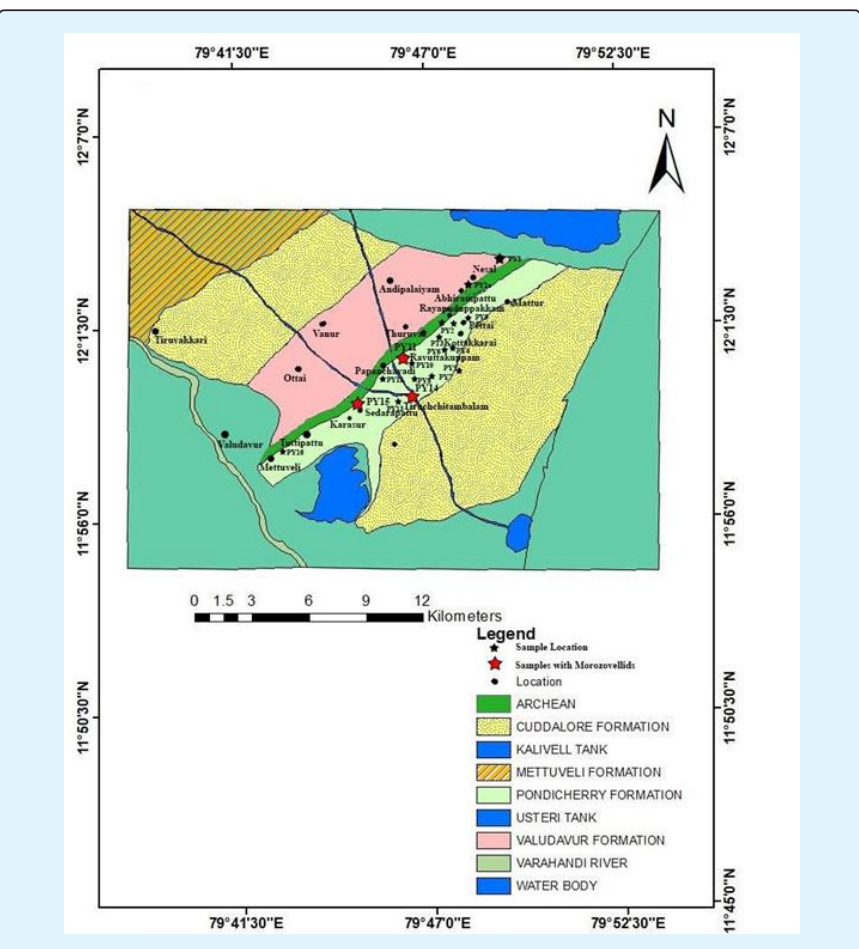

Figure 1: Geological map of Pondicherry area, Cauvery Basin, Southern India. 


\section{International Journal of Paleobiology \& Paleontology}

The Palaeocene -Eocene sediments of the Pondicherry area is known for its microfossil content and were studied by number of workers on various aspects [1-14]. Samples were collected from various outcrop sections and were processed in the laboratory for foraminifera using standard processing technique, have yielded abundant well preserved planktonic foraminifera belonging to the genus Morozovella, which are well known guide fossils of the Palaeocene - Eocene age.

\section{Materials and Methods}

Twenty-four Samples were collected from the study area for the planktic foraminiferal study. Major lithology of the section is Calcareous Sandstone and Marl contains numerous ichnofossilos and larger benthic foraminifera. The sample collected from the field was disaggregated for microfossil separation following standard procedure as detailed in our previous papers [14].

\section{Planktonic Foraminifera}

Planktic foraminifera are generally common to abundant throughout the carbonate facies of the Pondicherry sequence. The angulo-conical Morozovella constitutes the dominant element in the assemblage and are represented by fourteen species, viz., Morozovella aequa, $M$. angulata, $M$. subbotinae, $M$. gracilis, $M$. velascoensis, M. formosa, M. apanthesma, M. acutispira, $M$. praeangulata, M. occlusa, M. acuta, M. conicotruncata, $M$. lensiformis and M. crater are of late Palaeocene - early Eocene in age are reported from these sediments (Plates 1\&2). The Morozovella velascoensis is the highly specialized angulo-conical form with large, conical test, wide open umbilicus with prominent peripheral keel is the most distinctive and dominant form in the fauna [14].

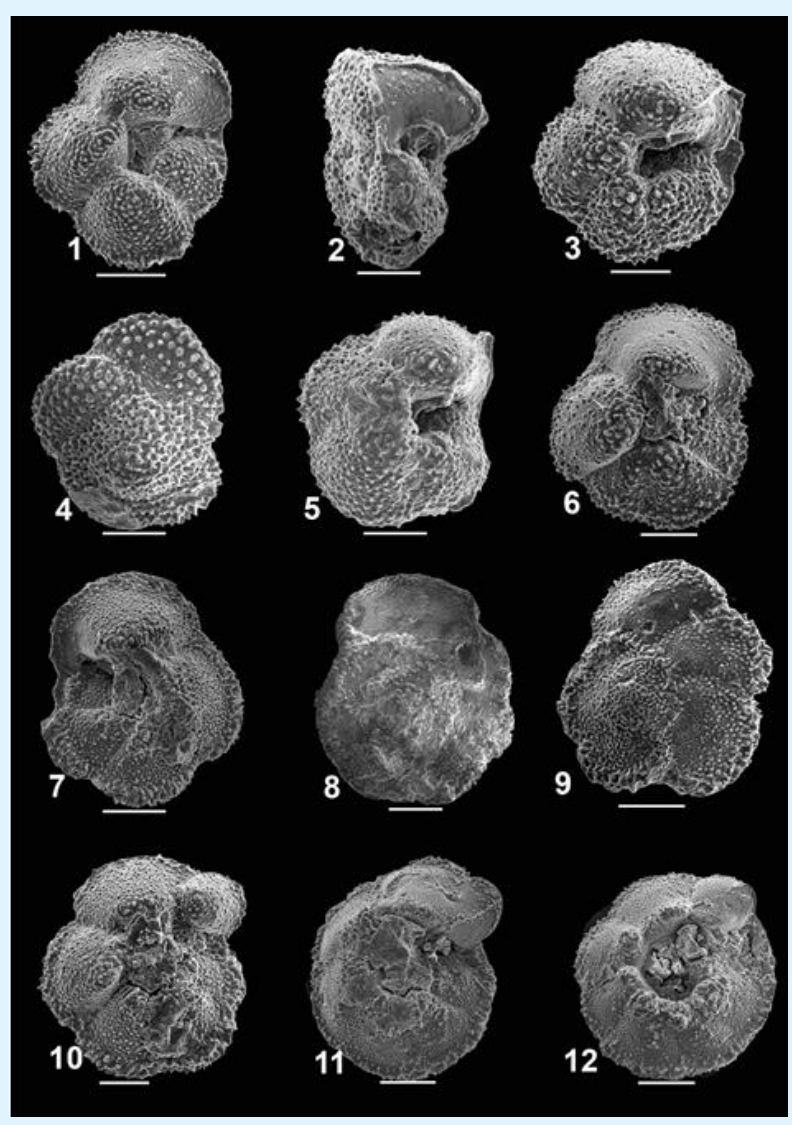

Plate 1: Morozovellids from Ravathamkuppam(PY11) and Saiderpet-Tiruchitrambalam cross-road sections(PY14). Scale bar $=100 \mu \mathrm{m}$. Figure $1 \& 2$ Morozovella aequa Samples PY14a, PY11a, b,c; Figure 3 M. lensiformis sample PY14a; Figures 4\&5 M.crater sample PY14a; Figure 6 M. gracilis sample PY14a; Figure 7 M. subbotinae sample PY14a; Figure 8 M. conicotruncata sample PY14c; Figure 9 \& 10 M. formosa sample PY14a ; Figure 11\&12 M.velascoensis sample PY14a. 


\section{International Journal of Paleobiology \& Paleontology}

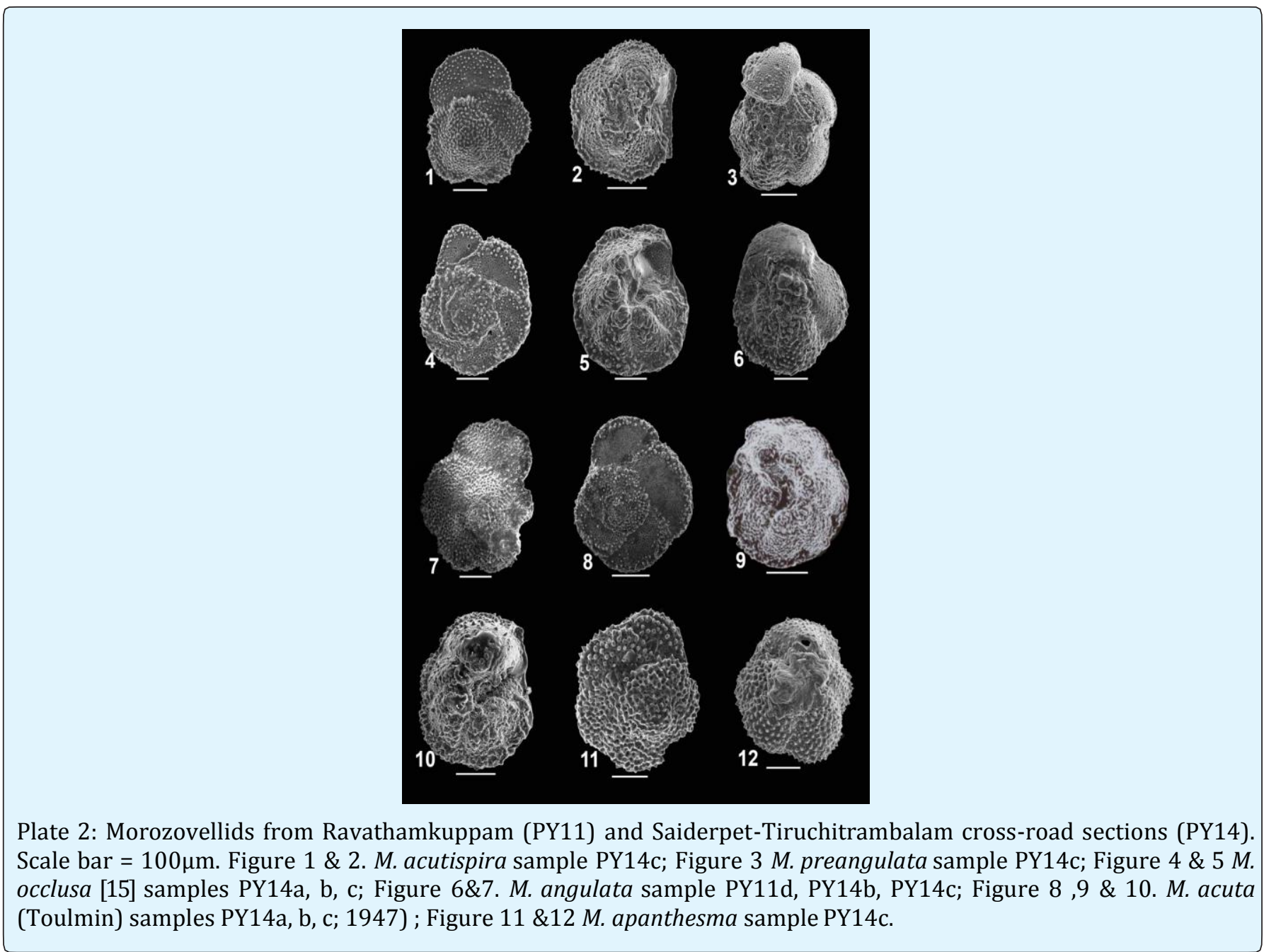

The muricate planktonic foraminiferal genera Morozovella are extensively utilised as palaeoclimatic studies and are important markers in Palaeocene - Eocene planktonic foraminifera biostratigraphy. Morozovella were prominent surface dwellers within the tropical and subtropical fauna [16,17], The recorded Morozovella species indicates that these sediments have been deposited during late Palaeocene - early Eocene age (P3E4).

\section{Diagnostic Characters of the Morozovella Species}

Morozovella velascoensis is characterised by relatively large robost, plano-convex, nearly circular, moderately lobulated test; composed of about 15-16 chambers arranged in 21/2 to 3 whorls; last whorl with 6-7 (rarely 8) anguloconical chambers whose tips surround a moderately open umbilicus surrounded by an rim of fused muricae; umbilical sutures radial, depressed, strongly curved raised and beaded on spiral side; wall finely perforated, distinctly muricocarinate periphery, but the spiral chamber surfaces often nearly free of muricae; aperture low, interiomarginal, umbilical- extraumbilical arch. Morozovella velascoensis has a wide geographic distribution but is a predominantly (sub)tropical to temperate form; it has not been recorded from high northern or southern (subantarctic) latitudes. The disappearance of this taxon is a distinct biostratigraphic event that is used to define the boundary between Zones P5 and P6, which occurs in Paleocene/Eocene boundary as denoted in the Belgian and/or London-Hampshire Basin(s) of northwestern Europe [18]. This species occurs at Zone P3b to Zone P5 [19]. The LAD of Morozovella velascoensis marks the base of zone E3 / top of E2 [20]. Last occurrence (top): at top of E2 zone (55.2Ma, in Ypresian stage). Data source: zonal marker [20]. First 


\section{International Journal of Paleobiology \& Paleontology}

occurrence (base): near base of P3b subzone (61.3Ma, in Selandian stage). Data source: Olsson, et al. [19]. This species occurs at P5 Zone in the study area (Plate 1: Figures 11 \& 12).

Morozovella aequa is having subquadrate, planoconvex, muricocarinate test with moderately lobulate peripheral outline and 4 (less commonly 5) chambers in last whorl; intercameral sutures on umbilical side straight; radial; raised, curved on spiral side, umbilicus narrow, low apertural slit extending to periphery; test surface covered with muricae, on umbilical shoulder and along peripheral margin [19]. Morozovella aequa is a geographically widespread species, having been recorded from areas circumscribed by latitudes $50^{\circ} \mathrm{N}$ (Goban Spur, northeastern Atlantic Ocean) [21] and $50^{\circ} \mathrm{S}$ (Falkland Plateau) [22]; it occurs as far south as nearly $60^{\circ}$ (Kerguelen Plateau) [23] during the brief early Eocene (Zone P6) temporal excursion of (sub)tropical Morozovellids. [19]. This species occurs at Zone P4c to Zone P7 [19]. Last occurrence (top) at top of E5 zone (50.7Ma, in Ypresian stage). First occurrence (base) at base of P4c subzone (57.8Ma, in Thanetian stage). Data source: Olsson, et al. (1999) [19]. This species occurs at P4-P5 Zone in the study area (Plate 1: Figures 1 \& 2).

Morozovella acuta is conicotruncate, distinctly muricocarinate test with 5 chambers in last whorl; intercameral sutures radial, depressed on umbilical side and strongly recurved and tangential, distinctly ornamented on, and flush with, spiral side; periumbilical collar weakly to moderately well-ornamented with muricate; umbilicus wide and open but narrow in more tightly coiled individuals; aperture interiomarginal, umbilical-extraumbilical with well-developed, triangular, circumumbilical "teeth. [19]. Morozovella acuta is an essentially subtropical to tropical form with somewhat narrower biogeographic distribution than $M$. velascoensis $[15,19]$. This species occurs at Zone P4b to Zone E2 (top) [24] Zone P4b to Zone P5 (top). Several authors suggest that $M$. acuta occurs somewhat higher than $M$. velascoensis. Last occurrence (top) at top of E2 zone (55.2Ma, in Ypresian stage). First occurrence (base) near base of $\mathrm{P} 4 \mathrm{~b}$ subzone (60.2Ma, in Selandian stage). Data source: Berggren, et al. (2006) [24]. This species occurs at P4 Zone in the study area (Plate 2: Figures 8,9 \& 10).

Morozovella acutispira is characterised by lenticular to subcircular, plano-convex to biconvex test with apiculate early whorls and lobulate outline, 4-6 chambers in last whorl; umbilical sutures radial, slightly curved, depressed; spiral sutures curved, raised and ornamented by the extension of the strongly muricate keel; chambers tend to be flattened along the peripheral margin; aperture a low, interiomarginal, umbilical-extraumbilical arch extending from a narrow, deep umbilicus [19]. The geographic distribution of this morphospecies appears characteristic of subtropical to tropical regions as does that of occlusa [19]. This species occurs near the Zone P3/P4 boundary to the top of Zone P4b [19]. Last occurrence (top) at top of P4b subzone (57.8Ma, in Thanetian stage). First occurrence (base) at top of P3b subzone (60.8Ma, in Selandian stage). Data source: Olsson, et al. (1999) [19]. This species occurs at P5 Zone in the study area (Plate 2: Figures 1 \& 2).

Morozovella occlusa is characterised by plano-convex to low biconvex, nearly circular test, 4-6 (rarely up to 8) chambers in last whorl, coalescing in a circular, subacute, weakly to moderately muricate umbilical shoulder and forming a narrow, deep umbilicus; umbilical sutures depressed, radial; elevated and beaded, tangentially curved on spiral side; sutures between final and penultimate whorl coarsely muricate; periphery distinctly muricocarinate; aperture an interiomarginal, umbilicalextraumbilical arch [19]. This species is widespread in the low to middle latitudes [19]. This species occurs at the Top of Zone P3b; Zone P4-P5 [19]. Last occurrence (top) at top of E2 zone (55.2Ma, in Ypresian stage). First occurrence (base) near top of P3b subzone (60.8Ma, in Selandian stage). Data source: Olsson, et al. (1999) [19]. This species occurs at P5 Zone in the study area (Plate 2: Figures 4 \&5).

Morozovella angulata is characterized by by muricate, nonspinose angulo-conical test, spiral side flat, early chambers slightly elevated, 10-12 chambers arranged in 21/2 whorls, 4-6 chambers in final whorl, periphery lobulate, (sub)acute, imperforate band (muricocarina) developed along peripheral margin; weak circumumbilical collar formed around narrow, deep umbilicus by elevated chambers, particularly last chamber; sutures depressed, straight, radial on umbilical side, strongly recurved on spiral side; aperture, low, interiomarginal, umbilical- extraumbilical low arch with weakly developed lip [19]. This form is essentially restricted to (sub)tropical to temperate regions; it has not been reliably reported from high northern or southern (subantarctic) regions [19]. This species occurs at Zone P3 to lower Zone P4 [19]. The FAD of Morozovella angulata marks the base of zone P3a / top of P2 [20]. Last occurrence (top) within P4a subzone (60.52-60.73 Ma, top in Selandian stage). First occurrence (base) at base of P3 zone (62.3Ma, in Danian stage). Data source: zonal marker [20]. This species occurs at P3a- P4 Zone in the study area (Plate 2: Figures $6 \& 7$ ). 


\section{International Journal of Paleobiology \& Paleontology}

Morozovella apanthesma is having panoconvex, umbilicoconvex, test with lobulate, weakly muricocarinate periphery; 4-5 chambers in last whorl, inflated to subangular on umbilical side, moderately convex, triangular (lunate) in edge view; intercameral sutures on umbilical side depressed, radially curved and slightly depressed on spiral side; umbilical side distinctly muricate, coarsely perforate on spiral side; umbilicus relatively narrow, deep; aperture an interiomarginal, umbilical-extraumbilical arch with narrow, continuous intraperiumbilical lip [19]. This species is distributed in Northern middle latitudes to the Southern Ocean [19].

This species occurs at Zone P3b to Zone P4c [19]. Last occurrence (top) at top of $\mathrm{P} 4 \mathrm{c}$ subzone $(57.1 \mathrm{Ma}$, in Thanetian stage). First occurrence (base) at base of P3b subzone (61.3Ma, in Selandian stage). Data source: Olsson, et al. (1999) [19]. This species occurs at P3b- P4 Zone in the study area (Plate 2: Figures $11 \& 12$ ).

Morozovella subbotinae is distinguished by its relatively large and strongly muricocarinate test, and the circumumbilical elevation/extension of the chambers and weakly ornamented circumumbilical chamber tips [24]. Widely distributed in (sub)tropical assemblages in Atlantic, Indo-Pacific, and typical Tethyan biogeographies and as far south as $60 \mathrm{o} \mathrm{S}$ in association with the early Eocene extra-tropical excursion of carinate morozovellids on the Kerguelen Plateau (ODP Site 738; ODP Site 747; text-figure 24;) $[19,25,23]$. We have found that $M$. subbotinae has its FAD at the $t$ base of P5 zone (57.1Ma, in Thanetian stage). Data source: Berggren, et al. (2006) [24]. This species occurs at Zone P5 to Zone E5. Its LAD is used to denote the boundary between Zones E5 and E6. The premature disappearance of $M$. subbotinae (within Zone $\mathrm{P} 6 \mathrm{~b}=\mathrm{E} 4)$ at Indian Ocean Site 213 is ascribed to gradually increasing dissolution in the early Eocene (Berggren \& Pearson 2006). The LAD of Morozovella subbotinae marks the base of zone E6 / top of E5. Last occurrence (top) at top of E5 zone (50.7Ma, in Ypresian stage). Data source: zonal marker [20]. First occurrence (base) at base of P5 zone (57.1Ma, in Thanetian stage). Data source: Berggren, et al. (2006) [24]. This species occurs at P5 Zone in the study area (Plate 1: Figure 7).

Morozovella gracilis is distinguished by its planoconvex to moderately biconvex test, with lobulate peripheral margin ornamented with a well-developed muricocarina; 5-6 essentially equidimensional chambers in last whorl; umbilical intercameral sutures radial, straight, depressed; on spiral side strongly curved, distinctly muricate except for penultimate/ultimate chamber suture which is straight giving cuneiform shape to final chamber; umbilical surface covered with muricae, spiral side weakly muricate except for concentration of muricae along intercameral sutures and peripheral margin of ultimate whorl; small sutural openings along margin/junction of ultimate/penultimate whorl resulting from chamber addition along topographically separated/elevated muricate edges; umbilicus narrow, deep; aperture a low interiomarginal, umbilicalextraumbilical arch extending towards, but not to, the peripheral margin [19]. This is a geographically widespread morphospecies recorded predominantly from (sub)tropical biogeographies. It occurs as far south as nearly $60^{\circ}$ at ODP Sites 738 [26] and 747 [23] on the Kerguelen Plateau, southern Indian Ocean, as part of the earliest Eocene extra-tropical excursion of Morozovellids [19]. This species occurs in Zone P5 to Zone P6b [19]. Last occurrence (top) at top of E5 zone (50.7Ma, in Ypresian stage). First occurrence in upper part of E2 zone (55.4Ma, in Ypresian stage). Data source: Olsson, et al. (1999) [19]. This species occurs at P5 Zone in the study area (Plate 1: Figure 6).

Morozovella conicotruncata is characterized by subcircular, moderately lobulate, low trochospiral test with 5-7 subangular, inflated, essentially equidimensional chambers in last whorl, spiral side flat to slightly convex in early whorls; umbilical sutures straight to weakly curved, radial, incised; spiral sutures distinctly curved, incised; axial periphery (sub)acute, peripheral muricocarina variable, generally fused on early chambers of last whorl while later chambers generally subrounded; umbilicus narrow, deep; aperture a low interiomarginal, umbilicalextraumbilical slit [19]. As with its closely related sister taxon angulata, this form has a predominantly tropical to temperate distribution $\left(<45^{\circ} \mathrm{N}\right.$ and $\left.\mathrm{S}\right)$ and has not been reliably reported from high northern or southern (subantarctic) latitudes. It occurs in Zone P3 to lower Zone P4. Last occurrence (top) at top of P4 zone (57.1Ma, in Thanetian stage). First occurrence (base) near base of P3 zone (62.1Ma, in Danian stage). Data source: Olsson, et al. (1999) [19]. It is a common and distinct form in our material and is observed in Zone P4 (Plate 1: Figure 8).

Morozovella praeangulata is characterised by planoconvex, moderately lobulate test with 5-6 tangentially elongate chambers in last last whorl; umbilical sutures straight to weakly curved, depressed/incised; spiral intercameral sutures incised, weakly muricate, strongly recurved; peripheral margin strongly muricate but not muricocarinate; umbilicus narrow, deep with aperture an interiomarginal, umbilicalextraumbilical slit extending nearly to the peripheral margin [19]. This species has been identified in few 


\section{International Journal of Paleobiology \& Paleontology}

localities suggests a low to middle latitude distribution [19]. Morozovella praeangulata occurs in Zone P2 to Zone P3a [19]. Last occurrence (top) at top of P3a subzone (61.3Ma, in Selandian stage). First occurrence (base) near base of P2 zone (62.6Ma, in Danian stage). Data source: Olsson, et al. (1999) [19]. This species occurs at P3a Zone in the study area (Plate. 2: Fig.3).

Morozovella formosa is characterized by its relatively large, robust test, 6-7 (rarely 8) chambers and strongly muricate keel. It is distinguished from its antecedent $M$. gracilis by its larger, more robust test, larger number of chambers in the last whorl and wider umbilicus, and from its partially contemporaneous homeomorph, $M$. crater, by its more lobulate periphery and larger number of chambers in the final whorl and less ornamented test [24]. Widely distributed in (sub)tropical regions (Caribbean Sea, Atlantic, Pacific, Tethyan, Indian and Austral Oceans) [24]. This species occurs at the base of Zone E4 to top of Zone E6 [24]. Last occurrence (top) at top of E6 zone (50.2Ma, in Ypresian stage). Data source: Berggren, et al. (2006) [24]. First occurrence (base) at base of E4 zone $54.6 \mathrm{Ma}$, in Ypresian stage). Data source: zonal marker [20]. This species occurs in E4 Zone (within Zone P6 = E4) (Plate 1: Figures 9\&10).

Morozovella crater is characterised by $4 \frac{1 / 2}{2}$ to 5 essentially equidimensional chambers in last whorl, thickened circumumbilical rim of elevated chamber shoulders, strongly limbate sutures on spiral side [24]. Widely distributed in (sub)tropical areas of Atlantic, Mediterranean/ Tethyan, Pacific Oceans and austral regions [24]. This species occurs in Zone E4 to Zone E9 [24]. Last occurrence (top) in upper part of E9 zone (43.4Ma, in Lutetian stage. First occurrence (base) in lower part of E4 zone (53.8Ma, in Ypresian stage). Data source: Berggren, et al. (2006) [24]. This species occurs at E4 Zone ((within Zone P6 = E4) Zone in the study area (Plate 1: Figures $4 \& 5$ ).

Morozovella lensiformis is characterized by its subquadrate, involute, biconvex test with narrow umbilicus; test covered by moderately to densely distributed, blunt muricae obscuring, in some instances, the peripheral muricocarina; $4-4 \frac{1}{2}$ chambers in last whorl. Later forms exhibit transitional features to plano-convex, multicameral M. aragonensis [24]. Relatively common in (sub)tropical areas; South Atlantic Ocean, Indo-Pacific, North Caucasus, among others [24]. This species occurs at the base of Zone E4 to Zone E6 [24]. Last occurrence (top) in mid part of E6 zone (50.4Ma, in Ypresian stage. First occurrence (base) at base of E4 zone (54.6Ma, in Ypresian stage). Data source: Berggren, et al. (2006) [24]. This species occurs at E4 (within Zone P6 = E4) Zone in the study area (Plate 1: Figure 3).

\section{Discussion and Conclusions}

All of the samples analysed contained abundant planktonic foraminifera and the samples from Ravathamkuppam and Trichitramblam (PY14a, b \&c, PY11a, b, \& c) are dominated by the genus Morozovella. The samples are typically characterised by species of Morozovella viz., Morozovella aequa, M. angulata, M. subbotinae, M. gracilis, M. velascoensis, M. formosa, $M$. apanthesma, M. acutispira, M. praeangulata, M. occlusa, M. acuta, M. conicotruncata, , M. lensiformis, and M. crater indicating planktonic foraminiferal Zones P3- E4 (late Palaeocene- early Eocene).

Morozovella aequa is a geographically widespread species, having been recorded from Goban Spur, northeastern Atlantic Ocean, Falkland Plateau, Kerguelen Plateau during early Eocene. M. angulate is reported from high northern or southern (subantarctic) regions. Morozovella subbotina widely distributed in (sub) tropical assemblages in Atlantic, Indo-Pacific, and typical Tethyan biogeographies of early Eocene. $M$. gracilis is a geographically widespread and recorded predominantly in (sub) tropical biogeographies on the Kerguelen Plateau, southern Indian Ocean, as part of the earliest Eocene. $M$. velascoensis occurs in Paleocene/Eocene boundary in the Belgian and London-Hampshire Basin(s) of northwestern Europe. M. formosa widely distributed in (sub) tropical regions in Caribbean Sea, Atlantic, Pacific, Tethyan, Indian and Austral Oceans. Morozovella apanthesma is distributed in Northern middle latitudes to the Southern Ocean. M. acutispira, is characteristic of subtropical to tropical regions. M. praeangulata, species distributed in a low to middle latitude. M. occlusa, species is widespread in the low to middle latitudes. M. acuta, is an essentially subtropical to tropical form occurs in Indian Ocean. $M$. conicotruncata distributed predominantly in tropical to temperate distribution. $M$. lensiformis is relatively common in (sub) tropical areas; South Atlantic Ocean, Indo-Pacific, and North Caucasus. M. crater is widely distributed in (sub) tropical areas of Atlantic, Mediterranean/ Tethyan, Pacific Oceans and Austral regions. The species of Morozovella recovered from the study area is distinctive of tropical and subtropical environments of late Palaeocene- early Eocene.

\section{Acknowledgement}

The authors are gratefully acknowledged the Chairman, Department of Geology, Bangalore University, 


\section{International Journal of Paleobiology \& Paleontology}

Bangalore for the encouragement and facilities. This work is fully supported by the Department of Science of Technology Government of India, New vide research project no.SR/S4/ES:262/2007. The authors are grateful to the anonymous reviewers for the suggestions for the improvement of the paper

\section{References}

1. Blanford HF (1865) On the Cretaceous and other rocks of South Arcot and Trichinopoly Districts, India. Rec Geol Sur 4: 1-217.

2. Furon R, Lemoine $P$ (1939) Sur la existence due Nummulitique a Pondicherry. CR Acad Sc Paris v 207(26): 1424-1426.

3. Rama Rao L (1939) On the occurrence of an Eocene bed in the Pondicherry Cretaceous area. Current Science 8(4).

4. Rama Rao L, Narayana Rao SR, Nagappa Y (1940) On the occurrence of the foraminiferal genus Orbitocyclina in the Cretaceous rocks of the Trichinopoly District, S India. Current Science 9(3): 124-126.

5. Rama Rao L (1956) Recent contributions to our knowledge of the Cretaceous rocks of South India. Proceedings of the Indian Academy of Sciences 44(4): 185-245.

6. Sastry MVA, Rao BRJ (1963) Smaller foraminifera from Nerinea beds of Pondicherry, South India. Indian Minerals 17: 192-194.

7. Gowda S S (1964) The foraminifera of the South India Cretaceous Eocene. Ecologae Geologicae Helvetiae 57(1): 299-313.

8. Rajagopalan N (1964) Late Cretaceous and Early Tertiary Stratigraphy of Pondicherry, South India-A Prelimnary note: Bull. Geo Soc India 1(1): 738-748.

9. Rajagopalan N (1965) Late Cretaceous and Early Tertiary Stratigraphy of Pondicherry, South India Jour Geo Soc India 6: 104-121.

10. Rajagopalan N (1968) A Restudy of the Pondicberry formation. Mem 2 GeoI Soc India: 128-129.

11. Sundaram R, Rao PS (1986) Lithostratigraphy of Cretaceous and Paleocene rocks of Trichirapalli
District, Tamil Nadu, South India. Rec Geol Survey of India 115(5): 9-23.

12. Sundaram R, Henderson RA, Ayyasami K, Stilwell JD (2001) A lithostratigraphic revision and palaeoenvironmental assessment of the Cretaceous System exposed in the onshore Cauvery Basin, southern India. Cretaceous Res 22(6): 743-762.

13. Malarkodi N, Patel SJ, Fayazudeen PJ, Mallikarjuna UB (2009) Palaeoenvironmental Significance of Trace fossils from the Palaeocene Sediments of the Pondicherry Area, South India. Journal of the Geological Society of India 74: 738-748.

14. Malarkodi N, Devi UC, Bhargav Sharma CS (2013) Palaeocene to early Eocene Planktonic Foraminifera of the Pondicherry area, South India, Geol Soc Ind spl publ 1: 230-242.

15. Pearson PN, Shackleton NJ, Hall MA (1993) Stable isotope paleoecology of middle Eocene planktonic foraminifera and multi-species isotope stratigraphy, DSDP Site 523, South Atlantic. Journal of Foraminiferal Research, 23(2): 123-140.

16. Norris RD (1996) Symbiosis as an Evolutionary Innovation in the Radiation of Paleocene Planktic Foraminifera. Paleobiology 22(4): 461-480.

17. Berggren WA, Aubry MP (1996) A Late PaleoceneEarly Eocene NW European and North Sea Magnetobiochronologic Correlation Network. In: Knox RWO'B, et al. (Eds), Correlation of the Early Paleogene in Northwest Europe. Geological Society, Special Publication 101: 309-352.

18. Olsson RK, Berggren WA, Hemleben C, Huber BT (1999) Atlas of Paleocene Planktonic Foraminifera. Smithsonian Contributions to Paleobiology 1-252.

19. Wade BS, Pearson PN, Berggren WA, Pälike H (2011) Review and revision of Cenozoic tropical planktonic foraminiferal biostratigraphy and calibration to the geomagnetic polarity and astronomical time scale. Earth-Science Reviews, 104(1-3): 111-142.

20. Snyder SW, Waters VJ (1985) Cenozoic Planktonic Foraminiferal Biostratigraphy of the Goban Spur Region, Deep Sea Drilling Project Leg 80. In: de Graciannsky PC, et al. (Eds), Initial Reports of the Deep Sea Drilling Project, US Government Printing Office 80: 439-472. 


\section{International Journal of Paleobiology \& Paleontology}

21. Tjalsma RC (1977) Cenozoic Foraminifera from the South Atlantic, DSDP Leg 36. In: Barker PF, et al. (Eds) Initial Reports of the Deep Sea Drilling Project, Washington, D C: US Government Printing Office 36: 493-518.

22. Berggren WA (1992) Paleogene Planktonic Foraminifera Magnetobiostratigraphy of the Southern Kerguelen Plateau (Sites 747-749). In: Wise SW et al. (Eds) Proceedings of the Ocean Drilling Program, Scientific Results. College Station, Texas: Ocean Drilling Program 120: 551-569.

23. Loeblich AR, Tappan H (1957a) Planktonic Foraminifera of Paleocene and Early Eocene Age from the Gulf and Atlantic Coastral Plains. In: Loeblich AR (Eds) and collaborators, Studies in Foraminifera. Bulletin of the United States National Museum 215: 173-198.
24. Berggren WA, Pearson PN (2006) Taxonomy, biostratigraphy, and phylogeny of Eocene Morozovella. Cushman Foundation Special Publication 41: 343-376.

25. Huber BT (1991a) Planktonic Foraminifer Biostratigraphy of Campanian-Maestrichtian Sediments from Sites 698 and 700, Southern South Atlantic. In: Ciesielski PF, et al. (Eds) Proceedings of the Ocean Drilling Program, Scientific Results, College Station, Texas: Ocean Drilling Program 114: 281-298.

26. Huber BT (1991b) Paleocene and Early Neogene Planktonic Foraminifer Biostratigraphy of Sites 738 and 744, Kerguelen Plateau (Southern Indian Ocean). In: Barren J, et al. Proceedings of the Ocean Drilling Program, Scientific Results, College Station, Texas: Ocean Drilling Program 119: 427-449. 